\title{
Period of Internet Usage: An Indicator of the Buying Behaviour of Internet Users?
}

\author{
P J du Plessis, P G Mostert and E J North
}

Department of Marketing and Communication Management, University of Pretoria

\begin{abstract}
This article focuses on the experience of the Internet user with regard to purchasing goods and services. A self-administered survey, hosted on a dedicated website, was used as a data collection method and 1005 responses were received. It was found that the period of Internet usage significantly influenced the decision to purchase via the Internet. Another finding was that the period of Internet usage significantly influenced whether those shopping on the Internet searched for, or considered searching for, product and service information online prior to purchasing from non-Internet-based sellers.
\end{abstract}

JEL L86

\section{INTRODUCTION}

The expanding role of the high-tech global environment, in which consumers live, resulted in a substantial interest in the impact of the Internet on consumer buying behaviour. The Internet is widely acknowledged as a powerful and important distribution channel for marketers as well as a source of consumers. According to Schiffmann and Kanuk (2004: 5), through this medium prospective buyers not only have more access to information, but also more power than ever before by shopping for goods around the globe and around the clock from the convenience of their homes.

It is predicted that the Internet will impact the decision-making process of the consumer regarding buying and also improve the efficiency of the buying process (Richardson, 2001: 137 and Reibstein, 2002: 466). The time and cost of searching for product information, evaluating alternatives and negotiating terms are being cut down. Through this communication technology the Internet consumers have convenient access to the products with the lowest prices and highest quality. 
This view is supported by Smith (2002: 446), Prabhaker (2000: 158-171) and Sinha (2000: 44-45), who add that the advantages for the consumer include the availability of free information, easily obtainable from the Internet. The search for information is reduced to a few effortless keystrokes, whereas collecting the same information traditionally would require considerably more time and effort. The Internet also offers direct information on product features, the quality of products and reliability of different suppliers, which shortens the time searching for information considerably compared to the non-Internet environment. Prices can be compared in real time at various online price comparison sites; purchasing experiences by previous buyers are frequently also available.

It is important for marketers to have a thorough understanding of the Internet user, who purchases online or searches for product and service information online prior to purchasing from non-Internet-based sellers. Knowledge about consumer decision-making and buying behaviour and the way consumers choose products will ensure more focused strategies to purchase a marketer's product as opposed to that of a competitor.

Markets can be served more effectively and profitably if Internet marketers understand the underlying reasons for differences in consumer choices (Phau \& Poon, 2000: 102). Since online buying is a relatively new consumer activity, it is expected that experience as an Internet user can influence buying behaviour.

This article focuses on the experience of the Internet user and specifically whether the period of Internet usage significantly influences the Internet user's buying behaviour. Attention will also be given to the actual purchases on the Internet and the search for information via the Internet and subsequent purchases offline.

\section{LITERATURE REVIEW}

The Internet can most probably be viewed as an additional sales channel and information search medium (and information source) that consumers can consider when purchasing products and services. Bickerton, Bickerton and Pardesi et al. (2000: 149) note that not all products and services are equally suited to be sold via the Internet. Greenbury, in Maruca (1999: 160) supports this view by stating that people will increasingly want to shop on the Internet for at least a certain range of products because of convenience. Therefore, marketers are interested in understanding the relationship between a consumer's choice of channel and the information search via the Internet. 
E-retailing will continue to establish itself as an alternative channel, alongside traditional shopping (Rowley, 2000: 20-35); buying certain items (apparel) online represents a new form of consumer behaviour (Hoffman and Novak, 1996). Consumers can benefit from a much wider selection of products to choose from since they are not bound to a certain selection of merchandise options, as is the case with traditional channels. McQuitty and Peterson (2000: 233-48) argue that online shoppers can seek virtually any product at any time and from any location. Consumers who desire extraordinary value can find the best deals by knowing which websites offer a given product and at what price. This is very similar to traditional shopping, but the Internet provides consumers with an extraordinary search power, where a large number of websites can be visited with ease - which is virtually impossible in the traditional shopping environment.

Therefore, from a consumer purchasing point of view, consumers have a choice between different outlets from which to purchase a product or service. Phau and Poon (2000: 102-13) explain that a number of factors influence the choice between a retail store and in-home shopping methods, such as mail order, telephone order and the Internet. These influences include socio-economic and demographic factors, product type and distribution methods, perceived purchase risk, personal characteristics and traits as well as shopping or delivery time.

Other possible factors influencing the channel selection include confrontation and contact control, manufacturer or brand reputation, type and source of the offer and price and refund or exchange policies. Phau and Poon (2000: 102-13) suggest that when in-house shopping is extended to Internet shopping malls, the listed factors will become more apparent.

As indicated above, the Internet may highlight factors influencing and affecting consumer decision-making. Research regarding Internet users emphasises these influences and supports the view that such influences need to be considered to understand consumer differences before attempting to draft strategies to sell products and services to consumers through the Internet. Research findings regarding the age, gender and education of Internet users show the possible influence of these demographic variables on the purchasing behaviour of Internet users.

Although Trocchia and Janda (2000: 605-16) mention a valid limiting factor associated with age, namely that older individuals often suffer from physical disabilities, older individuals could possibly represent an opportunity to Internet marketers due to their higher levels of free time and discretionary income when compared to younger individuals. 
Another factor to bear in mind is that Internet users are predominantly male and are more likely to engage in downloading from and purchasing on the Internet than females (Teo, 2001: 125-37).

In addition to age and gender, Hanson (2000: 117) provides a valuable perspective on education by stating that, after income, it forms the most important demographic variable determining Internet usage, since education enables users to operate and appreciate computers and the Internet.

The Internet provides consumers with an additional source of information and sales channel. Since the Internet has grown and shown advantages for both sellers and consumers, a number of traditional offline retailers have decided to offer their products and services to their customers via the Internet as an additional sales and information channel.

Nunes, Wilson and Kambil (2000: 20) explain that it is easy to see why traditional sellers are moving to the Internet to offer more ways to buy from them. They recognise that the same buyer may prefer different transaction mechanisms under different circumstances. For example, a consumer may not care about flight ticket prices when travelling for business, but may seriously consider lower prices when planning a family vacation. Nunes et al. (2000: 20) explain that by offering multiple transaction approaches, sellers could possibly win a larger share of existing consumers' business and also gain new types of purchasers.

Gulati and Garino (2000: 113) state that an established traditional retailer benefits from offering the web as an additional sales channel, since it offers the seller instant credibility on the web (provided that the brand is recognised and respected). The seller's current customers will, therefore, provide nearly immediate traffic and revenue and new customers will know that the site is legitimate and fewer buyers will fear credit card fraud.

Traditional sellers using the Internet as an alternative sales channel will most probably be forced to offer the same prices as in the physical store so as not to confuse their current customers or leave them distrustful. The extent of offering online purchases by traditional sellers would, therefore, most probably depend on the strengths of existing distribution and information systems and their transferability to the Internet (Gulati \& Garino, 2000: 113).

From the above discussion it can be concluded that more traditional sellers are offering online purchasing to its current and potential new customers. Ghosh (1998: 129) explains that the decision to offer consumers an Internet sales channel could possibly be based on a driving force exerted by competitors or 
through consumer demand. It is therefore also important for traditional sellers to understand the needs of their customers to ensure that they offer alternative sales channels, for example the Internet, when customers demand an alternative channel.

Few studies in South Africa have been done to determine whether the experience of the Internet user (the period of Internet usage) significantly influences the Internet user's buying behaviour. Specific hypotheses to address this issue have been formulated and will be discussed below.

\section{HYPOTHESES}

The first hypothesis is concerned with the experience of the Internet user and whether the period of Internet usage has an influence on the decision to purchase on the Internet.

$\boldsymbol{H}_{1}$ : The period of Internet usage significantly influences the decision to purchase on the Internet.

The second hypothesis deals with the issue of search on the Internet for product and service information by Internet shoppers and non-shoppers before buying from non-Internet-based sellers.

$\boldsymbol{H}_{2}$ : The period of Internet usage significantly influences the decision of Internet shoppers and non-shoppers to search for product and service information on the net prior to purchasing from non-Internet-based sellers.

\section{METHOD}

To achieve the objective set for the study, a pluralistic approach was followed by first using a qualitative research technique (pre-test group), followed by a quantitative technique (surveys). The objectives set as outcomes from the pretest group included, among others, testing the questionnaire to be used during the quantitative phase of the study and ensuring that all the possible reasons that could influence Internet users when deciding to purchase via the Internet, were covered in the questionnaire.

A selection of Internet users was required to complete a self-administered questionnaire during the second, quantitative, stage. 


\section{Stage 1 Pre-test group}

A pre-test or focus group normally involves collecting data and the analysis and interpretation thereof through observing what people do or say. In this study, 94 Internet users participated in the pre-test group. The most important findings, together with actions taken based on the findings, were:

- $\quad$ respondents indicated that they considered more aspects when deciding to purchase via the Internet. Based on their comments, the number of issues considered by shoppers when buying via the Internet, increased from 17 to 24; and the issues were phrased as questions;

- questions that could have been misunderstood or misinterpreted were rephrased to provide commonly understood questions in the final questionnaire.

\section{Stage 2 Survey}

For the purpose of this study, it was decided to use a self-administered survey, hosted on a dedicated website, as data collection method. The website was designed in such a manner that respondents would automatically be directed to the next question applicable to them, based on their input to the questionnaire. The responses were captured in a database only after respondents had completed the entire questionnaire.

\section{Sampling}

For the purpose of the study, probability sampling was used. After careful consideration of the different probability sampling methods (Simple random, Systematic, Stratified and Cluster sampling - Cooper and Schindler, 2001: 190), and paying attention to the advantages and disadvantages of each method (with specific consideration of the and hypotheses formulated for the study), it was decided to use the stratified method of sampling. The reason why the hypotheses set for the study played such an important role in deciding which sampling method to use can be justified - the length of time of a consumer being an Internet user is of critical importance to the success of the study since the hypotheses centre around identifying possible relationships with the period of being an Internet user.

Simple random sampling was used to draw 5000 subscribers for each of four different periods (strata) specified from which the sample elements had to be chosen. The sample units were randomly selected, following a ratio between the number of Internet users in each time period and the total number required for each period. 
An e-mail message was distributed to the selected 20000 South African Internet users, inviting them to participate in the study. The letter briefly described the purpose of the study and contained a link that would, if clicked on, route interested Internet users directly to the website where the questionnaire was hosted.

\section{Survey participants}

A total of 1005 respondents (aged between 18 to 65) completed the questionnaire. Of the 1005 respondents, 543 (54 percent) indicated that they have purchased via the Internet before while 462 (46 percent) indicated that they have never purchased online. Internet shoppers comprised 415 (76 percent) male and 128 (24 percent) female respondents, while non-shoppers consisted of 288 (62 percent) male and 174 (38 percent) female respondents.

\section{ANALYSIS}

Cronbach's alpha, representing a measure of internal consistency reliability (Malhotra, 1996: 305) with values ranging between 0 and equal to 1 , with higher numbers indicating greater reliability, was computed to determine the reliability of the questionnaire used in the study. For exploratory research a Cronbach alpha greater than 0.60 is desired, although values greater than 0.70 are preferred (Bagozzi, 1994: 18). Cronbach's alpha computed for instrument items of this study is 0.891 , indicating a relatively high internal consistency reliability.

Table 1 indicates the period of Internet usage for respondents who participated in the study.

A relatively large percentage (35 per cent) of the respondents have been using the Internet for more than four years and the "less than one year" time period represents the least number of respondents (11 per cent).

\section{Table 1 Period of Internet usage}

\begin{tabular}{|l|c|c|}
\hline \multicolumn{1}{|c|}{ Period of Internet usage } & $\begin{array}{c}\text { Frequency } \\
\text { (n=1005) }\end{array}$ & Percentage \\
\hline Less than 1 year & 113 & $11.24 \%$ \\
\hline 1 year to less than 2 years & 133 & $13.23 \%$ \\
\hline 2 years to less than 3 years & 205 & $20.40 \%$ \\
\hline 3 years to less than 4 years & 198 & $19.70 \%$ \\
\hline 4 years or more & 356 & $35.42 \%$ \\
\hline
\end{tabular}


A cross-tabulation between the period of Internet usage and whether or not respondents have purchased via the Internet is presented in Table 2.

Table 2 Relationship between Internet shoppers, non-Internet shoppers and period of Internet usage

\begin{tabular}{|c|c|c|c|}
\hline \multirow[t]{2}{*}{ Period of Internet usage } & \multicolumn{2}{|c|}{$\begin{array}{l}\text { Purchased via the } \\
\text { Internet }\end{array}$} & \multirow[t]{2}{*}{ Total } \\
\hline & Yes & No & \\
\hline Less than 1 year & 23 & 90 & 113 \\
\hline 1 year to less than 2 years & 50 & 83 & 133 \\
\hline 2 years to less than 3 years & 100 & 105 & 205 \\
\hline 3 years to less than 4 years & 112 & 86 & 198 \\
\hline 4 years or more & 258 & 98 & 356 \\
\hline Total (Frequency) & 543 & 462 & 1,005 \\
\hline (Percentage) & $54.03 \%$ & $45.97 \%$ & $100 \%$ \\
\hline
\end{tabular}

Although observable differences can be noted when comparing whether or not respondents have purchased via the Internet before when considering the different time periods, it is important to determine whether or not differences can be supported statistically.

A chi-square test was used for significance testing and yielded a value of 117.60 with an exceedence probability of $<0.0001$. When applying the decision-rule, which states that an exceedence probability value of $<0.05$ is an indication of significance, it can be deduced that the two variables portrayed in Table 2 are related.

The study also determined if the length of Internet usage could be considered an influence, when Internet users search for product and service information on the Internet prior to purchasing from non-Internet-based sellers. Table 3 depicts the responses of survey participants, showing that 86 percent of Internet shoppers and almost 70 percent of non-shoppers search for or consider searching for information on the Internet prior to purchasing from non-Internet-based sellers.

Based on these findings and taking into account the hypotheses formulated for the study, chi-square tests were performed to determine if the period of Internet usage was related to whether Internet shoppers and non-shoppers searched for or considered searching for online product and service information prior to purchasing offline. 
Table 3 Online information search prior to purchasing offline

\begin{tabular}{|c|c|c|c|c|}
\hline \multirow[t]{2}{*}{ Description } & \multicolumn{2}{|c|}{$\begin{array}{l}\text { Non-Internet } \\
\text { shoppers }\end{array}$} & \multicolumn{2}{|c|}{$\begin{array}{c}\text { Current Internet } \\
\text { shoppers }\end{array}$} \\
\hline & Frequency & Per cent & Frequency & Per cent \\
\hline $\begin{array}{l}\text { Search for or consider } \\
\text { searching for product and } \\
\text { service information on the } \\
\text { Internet prior to purchasing } \\
\text { from non-Internet-based } \\
\text { sellers }\end{array}$ & 322 & $69.70 \%$ & 469 & $86.37 \%$ \\
\hline $\begin{array}{l}\text { Don't search for and don't } \\
\text { consider searching for } \\
\text { product and service } \\
\text { information on the Internet } \\
\text { prior to purchasing from } \\
\text { non-Internet-based sellers }\end{array}$ & 140 & $30.30 \%$ & 74 & $13.63 \%$ \\
\hline
\end{tabular}

The first cross-tabulation analysis is illustrated in Table 4 and considers the period of Internet usage and whether non-shoppers search for product and service information on the net prior to purchasing from non-Internet-based sellers.

Table 4 Relationship between period of Internet usage and product and service information searched for online prior to offline purchases (non-Internet shoppers)

\begin{tabular}{|c|c|c|c|}
\hline \multirow[t]{2}{*}{$\begin{array}{lll}\begin{array}{l}\text { Period of } \\
\text { usage }\end{array} & & \\
\end{array}$} & \multicolumn{2}{|c|}{$\begin{array}{l}\text { Search or consider searching for } \\
\text { product and service information } \\
\text { online }\end{array}$} & \multirow[t]{2}{*}{ Total } \\
\hline & Yes & No & \\
\hline Less than 1 year & 46 & 44 & 90 \\
\hline $\begin{array}{l}1 \text { year to less than } 2 \\
\text { years }\end{array}$ & 55 & 28 & 83 \\
\hline $\begin{array}{l}2 \text { years to less than } 3 \\
\text { years }\end{array}$ & 77 & 29 & 106 \\
\hline $\begin{array}{l}3 \text { years to less than } 4 \\
\text { years }\end{array}$ & 63 & 23 & 86 \\
\hline 4 years or more & 81 & 16 & 97 \\
\hline Total (Frequency) & 322 & 140 & 462 \\
\hline (Percentage) & $69.70 \%$ & $30.30 \%$ & $100 \%$ \\
\hline
\end{tabular}


From Table 4 it can be deduced that a larger number of non-shoppers, across all time periods, either search for or consider searching for product and service information on the net prior to purchasing from non-Internet-based sellers than non-shoppers who don't search for information online. A second observation is that 83 percent (81/97) of non-shoppers who have been using the Internet for four years and more search for product and service information online prior to purchasing offline.

A chi-square test was performed for the summarised cross-tabulation shown in Table 4 to determine if a relationship exists between the period of non-shoppers using the Internet and searching for online product and service information prior to purchasing from non-Internet-based sellers. The chi-square test yielded a value of 23.85 and an exceedence probability of $<0.0001$. It can be concluded that the period of Internet usage and whether or not non-shoppers search for product and service information on the Internet prior to purchasing offline are related.

The same cross-tabulation procedure was repeated for respondents who have shopped via the Internet before. The results from a summarised cross-tabulation analysis are shown in Table 5.

Table 5 Relationship between period of Internet usage and product and service information searched for online prior to offline purchases (Internet shoppers)

\begin{tabular}{|c|c|c|c|}
\hline \multirow[t]{2}{*}{$\begin{array}{l}\text { Period of Internet } \\
\text { usage }\end{array}$} & \multicolumn{2}{|c|}{$\begin{array}{l}\text { Search or consider searching for } \\
\text { product and service information } \\
\text { online }\end{array}$} & \multirow[t]{2}{*}{ Total } \\
\hline & Yes & No & \\
\hline Less than 1 year & 16 & 7 & 23 \\
\hline $\begin{array}{l}1 \text { year to less than } 2 \\
\text { years }\end{array}$ & 42 & 8 & 50 \\
\hline $\begin{array}{l}2 \text { years to less than } 3 \\
\text { years }\end{array}$ & 83 & 17 & 100 \\
\hline $\begin{array}{l}3 \text { years to less than } 4 \\
\text { years }\end{array}$ & 94 & 18 & 112 \\
\hline 4 years or more & 234 & 24 & 258 \\
\hline Total (Frequency) & 469 & 74 & 543 \\
\hline (Percentage) & $86.37 \%$ & $13.63 \%$ & $100 \%$ \\
\hline
\end{tabular}

They confirm that larger numbers of current Internet shoppers, across all time periods, either search for or consider searching for product and service 
information on the net prior to purchasing from non-Internet-based sellers than current shoppers who don't search for online information. It can also be deduced that almost 91 percent (234/258) of respondents who have purchased via the Internet and have been using the net for four years and more, search for product and service information online prior to purchasing offline.

The chi-square test for significance performed for the summarised crosstabulation analysis depicted in Table 5 produced a value of 11.39 and a resulting exceedence probability of $<0.0225$. It can therefore be concluded that the period of Internet usage and whether or not Internet shoppers search for or consider searching for product and service information online prior to purchasing offline are related.

\section{DISCUSSION AND IMPLICATIONS}

Hypothesis 1 stated that the period of Internet usage significantly influenced the decision to purchase via the Internet. Based on the results of the chi-square test for significance, this hypothesis can be accepted.

It is suggested that marketers focus their attention on Internet users who have been using the Internet for at least a number of years. Marketers also need to consider methods to stimulate Internet service uptake, since greater success would probably only be achieved from a medium to long-term investment.

Hypothesis 2 concerns the influence of the period of Internet usage on the decision of Internet shoppers and non-shoppers to search for product and service information on the net prior to purchasing from non-Internet-based sellers. Two chi-square analyses were performed: from the first analysis, it could be concluded that the period of Internet usage significantly influences whether or not non-shoppers search for product and service information on the Internet prior to purchasing from non-Internet-based sellers.

The conclusion that can be drawn from the second chi-square analysis is that the period of Internet usage significantly influences the decision of Internet shoppers to search for or consider searching for product and service information online prior to purchasing from non-Internet-based sellers.

From these findings it can be concluded that the Internet users utilise the Internet as a powerful information source to search for product and service information prior to purchasing from non-Internet-based sellers of products and services. Hypothesis 2 can therefore be accepted. 
It is suggested that marketers should know and understand the importance of providing online product and service information (Internet users may, after searching online, purchase at a "brick-and-mortar" seller). Marketers have to seriously consider providing online information on the products or services they sell, even if they don't sell via the Internet. Marketers should, however, first determine whether or not Internet users search for (and more importantly consider searching for) information on the products or services they offer.

\section{FUTURE RESEARCH}

Future studies can be directed to the following areas:

- $\quad$ the possible differences in behaviour between male and female Internet users with regard to the period of Internet usage and buying behaviour

- $\quad$ the influence of ethnic orientation on Internet usage and Internet shopping

- the relationship of demographic variables of Internet shoppers and the type of products and services purchased via the Internet.

\section{CONCLUSION}

It is predicted that the Internet will have a great impact on the decision-making process of consumers regarding purchasing goods and services. For marketers to be successful on the Internet, they have to understand the Internet consumer and more specifically his/her decision-making process. Knowledge obtained about the way consumers choose products will ensure more focused strategies to influence a consumer to purchase a specific marketer's product as opposed to that of a competitor.

From this study it can be concluded that marketers who consider competing in the Internet environment need to pay special attention to the period of Internet usage of their target market in formulating strategies to pursue the Internet user. However, marketers are at risk of not being able to sustain their Internet business when the success thereof can be related to the experience of the Internet user.

\section{REFERENCES}

1 BAGOZZI, R.P. (1994) Principles of Marketing Research, Blackwell Publishers: Massachusetts. 
2 BICKERTON, P., BICKERTON, M. \& PARDESI, U. (2000) Cyber Marketing: How to Use the Internet to Market your Goods and Services, Butterworth Heinemann: Oxford.

3 COOPER, D.R. \& SCHINDLER, P.S. (2001) Business Research Methods ( $7^{\text {th }}$ ed.) McGraw-Hill Irwin: Boston.

4 GHOSH, S. (1998) "Making business sense of the Internet", Harvard Business Review, March/April.

5 GREENBURY, R. in MARUCA, R.F. (1999) "Retailing: Confronting the challenges that face brick-and-mortar stores", Harvard Business Review, July-August.

6 GULATI, R. \& GARINO, J. (2000) "Get the right mix of bricks \& clicks”, Harvard Business Review, May/June.

7 HANSON, W. (2000) Principles of Internet Marketing, South-Western College Publishing: Cincinnati.

8 HOFFMAN, D.L. \& NOVAK, T.P. (1996) "Marketing in hypermedia computer-mediated environments: conceptual foundations”, Journal of Marketing, 60(3): 153-61.

9 MALHOTRA, N.K. (1996) Marketing Research: An Applied Orientation ( $2^{\text {nd }}$ ed.) Prentice Hall: New Jersey.

10 MCQUITTY, S. \& PETERSON, R.T. (2000) "Selling home entertainment on the Internet: An overview of a dynamic marketplace", Journal of Consumer Marketing, 17(3).

11 NUNES, P., WILSON, D. \& KAMBIL, A. (2000) “The all-in-one market”, Harvard Business Review, May/June.

12 PHAU, I. \& POON, S.M. (2000) "Factors influencing the types of products and services purchased over the Internet", Internet Research: Electronic Networking Applications and Policy, 10(2).

13 PRABHAKER, P.R. (2000) “Who owns the online consumer?”, Journal of Consumer Marketing, 17(2).

14 REIBSTEIN, D.J. (2002) "What attracts customers to online stores, and what keeps them coming back?", Journal of the Academy of Marketing Science, 30(4).

15 RICHARDSON, P. (2001) Internet Marketing: Readings and Online Resources, McGraw-Hill/Irwin: New York.

16 ROWLEY, J. (2000) "Product search in e-shopping: A review and research propositions". Journal of Consumer Marketing: 17(1).

17 SCHIFFMAN, L.G. \& KANUK, (2004) Consumer Behavior, Pearson Prentice Hall: New Jersey.

18 SINHA, I. (2000) “Cost transparency: The net's real threat to prices and brands”, Harvard Business Review, March/April.

19 SMITH, M.D. (2002) "The impact of shopbots on electronic markets", Journal of the Academy of Marketing Science, 30(4). 
20 TEO, T.S.H. (2001) "Demographics and motivation variables associated with Internet usage activities”, Internet Research: Electronic Networking Applications and Policy: 11(2).

21 TROCCHIA, P.J. \& JANDA, S. (2000) “A phenomenological investigation of Internet usage among older individuals", Journal of Consumer Marketing, 17(7). 